\title{
Azeri-tyrkisk nasjonalisme
}

Irans azeri-tyrkere tok i 2006 til gatene. Under de store demonstrasjonene ble det ropt nasjonalistiske slagord rettet mot landets persere. Azerityrkere utgjør minst en fjerdedel av befolkningen, og innehar viktige posisjoner i Irans politikk. Hva er status for azeri-tyrkisk nasjonalisme?

Av Einar Wigen, MA i fred- og konfliktstudier fra EPU i Østerrike, studerer tyrkisk og statsvitenskap ved Universitetet i Oslo.

Den iranske statens fundament er landets to største grupper: perserne ${ }^{\mathrm{I}}$ og azeri-tyrkerne, ${ }^{2}$ og den bygger sin legitimitet på en kombinasjon av persisk-orientert iranisme og en fleretnisk islamisme. Om dette fundamentet skulle ryke, ville det få alvorlige følger for den iranske staten og for regionen. Til tross for de omfattende demonstrasjonene i 2006 og andre tegn på at azeri-tyrkisk nasjonalisme er på fremmarsj, er det gjort få studier av dette. Det er derfor på sin plass å vurdere aseri-tyrkernes stilling i Iran, og den azeri-tyrkiske nasjonalismens utvikling.

\section{Etniske relasjoner i det før-moderne Iran}

I tillegg til å utgjøre majoriteten av befolkningen i Republikken Azerbaidjan, er azeri-tyrkerne en etnisk minoritet i Iran. Deres tradisjonelle hovedområde ligger i nordvest: Irans to Azerbaidjan-provinser, samt Ardabil, Qazvin og Zanjan. Dessuten finnes azeri-tyrkere i alle landets større byer. De snakker et tyrkisk språk som er nesten identisk med det som snakkes i Republikken Azerbaidjan, og som ligger nært det som snakkes i Tyrkia. Azeri-tyrkerne er i hovedsak shiamuslimer, og tilhører dermed det religiøse flertallet i Iran. Det finnes ikke offisielle folketellinger som tar med språk i Iran, men azeri-tyrkerne utgjør anslagsvis et sted mellom en fjerdedel og Io6 en tredjedel av en befolkning på knappe 70 millioner. ${ }^{3}$ Ethnologue regner azeri-tyrkere for å utgjøre en større andel av Irans befolkning enn perserne, med henholdsvis 23,5 og 22 millioner. ${ }^{4}$ Til sammenligning er folketallet i Republikken Azerbaidjan omtrent åtte millioner.

En upresis, men nyttig forenkling av Irans samfunn i før-moderne tid er å se landet som sammensatt av to hovedgrupper: tyrkere og persere. Tyrkerne levde en nomadetilværelse, men var med noen få unntak opphav til de kongelige dynastiene i Iran mellom Iooo-tallet og I925. Perserne var bofaste og politisk underlegne, men deres kultur ble ansett som høykultur. ${ }^{5}$ Det er et paradoks i Irans historie at perserne hadde den kulturelle makten uten å inneha den politiske. En forklaring kan være at tyrkerne overtok et allerede eksisterende statsapparat, med et fullt sett institusjoner og tradisjoner da de kom til området, og at de i liten grad brukte tyrkere som administratorer. ${ }^{6}$

\section{Etnisitet og nasjon}

Etnisitet kan defineres som en sosial identitet basert på et metaforisk eller fiktivt slektskap mellom individer i kontrast til relevante andre.7 En "nasjon” oppstår når en etnisk gruppe gjør krav på suveren makt over et spesifikt territorium, også om de 
ikke oppnår dette. "Nasjonalisme” er den ideologien en nasjon bruker til å legitimere kravet, og går sammen med "nasjonsbygging”, som er tiltak for å binde sammen befolkningen $i$ et nasjonalt fellesskap. Nasjonsbygging blir som regel satt i gang etter at nasjonen oppnår målet om suveren makt i et territorium, og kan skape motreaksjoner blant de etniske grupper som faller utenfor den normen nasjonen bygges opp rundt. ${ }^{8}$

Den politiske maktens legitimerende prinsipp i Iran forut for den konstitusjonelle revolusjon var shia-islam. For de dynastiske rikene i Iran var Det osmanske riket lenge den definerende andre, i kraft av at det var sunnimuslimsk. Både Det osmanske riket og dynastiene i Iran trakk sitt opphav tilbake til de første kalifene, altså arabere, noe som ville gitt lite mening om språk var kilde til legitimitet. ${ }^{9}$ Et annet eksempel er at den første Safavidekongen i Iran, Ismael I, sendte brev på tyrkisk til den osmanske Sultan Selim I, som sendte sitt svarbrev på persisk. I førmoderne tid var altså ikke språket viktig for hvordan politiske ledere legitimerte sin makt i regionen, og både Det osmanske og rikene i Iran var flerspråklige riker.

For Iran ble Det osmanske riket i løpet av I80o-tallet et eksempel til etterfølgelse i reformprosessen. I begge statene ble det å danne en moderne nasjonalstat ansett som den eneste muligheten til å forsvare seg mot europeiske makters koloniale fremrykk. Man antok at for å skape en moderne nasjonalstat var det nødvendig å skape homogenitet rundt én identitet, med ett felles språk.

Iran stod, ifølge den iranske akademikeren Mostafa Vaziri, overfor valget mellom islamisme, regionalisme eller iranisme som legitimerende prinsipp for sin nasjonsbygging. Iranismen baserer seg på ideer som i følge Vaziri ble brakt til Iran ı8oo-tallet, da orientalistene introduserte iranerne for en nasjonsbasert forståelse av verden. De vestlige orientalistene konstruerte noe Vaziri kaller "den ariske modellen". Iranerne var nedstammet fra en av de ariske urstammene, og hadde mot alle odds overlevd og klart å bevare sitt språk og sin kultur gjennom nesten 5000 år. ${ }^{\text {I0 }}$ Språket og kulturen var persisk, og ideen om deres overlegenhet ble koblet til en idé om et rettmessig krav på den iranske statens territorium.

Persisk var forut for den moderne nasjonalstaten "lingua franca" i Iran og i enkelte naboland. Pahlavi-regimet, som kom til makten i I925, brukte orientalistenes tanker i nasjonsbyggingen og satte likhetstegn mellom språket persisk, Qajardynastiets territorium og dets innbyggere. Slik forsøkte man å skape et språklig fellesskap, slik at innbyggerne kunne forstå hverandre, dele de samme mytene og den samme selvforståelsen. På denne måten fikk iranismen konsekvenser for hvordan regimet formet den iranske nasjonen.

Ifølge den azeri-tyrkiske historikeren Touraj Atabakı var den konstitusjonelle revolusjonen i I905-09, der azeri-tyrkerne spilte en viktig rolle, Irans første viktige skritt fra dynastisk rike til nasjonalstat. Mange av de ledende pådriverne for en iransk nasjonalstat kom fra ikke-persiske minoriteter, og de fremste av disse var azeri-tyrkere. Ifølge Atabakı var det Det osmanske rikets invasjon av Tabriz i slutten av første verdenskrig, og dets pan-tyrkisme, som gjorde at en liten gruppe azerityrkiske intellektuelle ble viktige forkjempere for Irans territorielle integritet og suv- 
erenitet. ${ }^{\text {II }}$ Da sjah Reza Pahlavi kom til makten i i925, kom skolene til å spille en viktig rolle i nasjonsbyggingen. Det ble lagt vekt på persisk språk, iransk historie (der arianismen stod sentralt), geografi (Irans territorielle enhet) og patriotiske sanger. Likevel var ikke dette noe som ekskluderte de andre etniske gruppene fordi "iranisme og islamisme blandet seg tilstrekkelig til at den iranske identiteten bar med seg en tosidig idé om shi'i-tanker og den sekulære monarkiske tradisjonen i regionen." ${ }^{{ }_{12}}$ En form for etnonasjonalisme, inspirert av europeiske ideer om arisk raseoverlegenhet, blandet seg med den eksisterende religiøse legitimeringen av staten. Iransk nasjonalisme var for azeri-tyrkerne tveegget: på den ene siden var de ikke statens titulærgruppe, men samtidig var den azeri-tyrkiske eliten de ivrigste iranske nasjonalistene.

\section{Det tyrkiske eselet}

Tyrkisk identitet har, som vi har sett, eksistert i Iran også forut for moderniteten, selv om denne da var underordnet en rekke andre identiteter. Gruppen "tyrker" slik den ble forenklet innledningsvis, omfattet mange tyrkiske grupper som i dag regnes som ulike etniske grupper. Men en oppfatning av tyrkernes rolle i samfunnet som mindreverdig er fremdeles utbredt i Iran i dag.

Det finnes et ofte brukt persisk uttrykk, khar-e tork, som betyr "det tyrkiske eselet". ${ }^{13}$ Dette er en stereotypi av tyrkeren som ærlig, hardtarbeidende, dum og ukultivert. Slik stereotyper ofte gjør, representerer den en stilisert kortform av oppfatningene om azeri-tyrkere og andre tyrkiske grupper i Iran. Ettersom målestokken for hvorvidt man er kultivert og sivilisert i Iran er i hvilken grad man behersker persisk språk og kultur, anses en azeri-tyrker per definisjon som mindre kultivert enn en perser. I hvert fall så lenge han ikke har tilegnet seg deres kultur.

Det som skiller azeri-tyrkere fra de øvrige tyrkiske folkene i Iran har å gjøre med deres politiske og geografiske posisjon i før-moderne historie. Ettersom Irans politiske dynastier utgikk fra dem, var de nærmere makten enn andre tyrkiske grupper. I tillegg er azeri-tyrkere i hovedsak shiamuslimer, i motsetning til de andre tyrkiske gruppene, som er sunnimuslimer. Dette har sammenheng med at sjah Ismael I, som opprettet Det safavidiske dynastiet i det sekstende århundret og gjorde shiaislam til statsreligion, var etnisk azeri-tyrker og hadde Tabriz i Azerbaidjan som sin hovedstad. Forøvrig var Tabriz setet til den iranske arveprinsen og nøt status som en slags andre hovedstad helt frem til I920tallet. Azerbaidjan var gjennom det nittende århundre Irans vindu mot Russland og Det osmanske riket, og dermed den delen som mottok de nyeste ideene og den nyeste teknologien først.

Azeri-tyrkere har klart seg meget bra i Irans samfunnsliv, og er godt representert blant de religiøst lærde og til dels også i politikken. ${ }^{\text {it }}$ Alle som har klart seg innen en av disse arenaene har imidlertid klart det gjennom assimilering og persefisering. Nåværende Øverste leder i Iran, Ali Khamene'i, trekkes ofte frem som et eksempel på en azeri-tyrker som har klart seg godt i politikken. Han har adoptert persisk kultur og språk, og får dermed de samme mulighetene for å hevde seg i Irans samfunnsliv som persere. Khamene'i er kanskje også essensen av iranismen: en azeri-tyrker som har tatt til seg persisk 
språk og kultur og som styrer Iran gjennom båndet av shia-islam.

\section{Motreaksjoner på nasjonsbyggingen}

Ettersom nasjonsbygging kan føre til motreaksjoner hos etniske grupper som faller utenfor den nasjonale normen, er det i motreaksjonene mot iranismen man kan studere en eventuell azeri-tyrkisk nasjonalisme. Av konkrete politiske bevegelser som mellom I925 og I979 artikulerte motprogram mot sjahens persiske stat og mobiliserte på bakgrunn av det, finnes det et opprør i I945 og en fløy i den islamske revolusjonen i I979.

Under sovjetisk okkupasjon ble det i I945 gjort opprør i Tabriz, kjent som Pishevari-revolusjonen. Dette opprøret var ikke rettet mot Sovjetunionens okkupasjon, men mot sentralmyndighetene i Teheran. Lederen for opprøret, Sayyad Ja'far Pishevari, var oppsatt på å sikre azeri-tyrkerne kulturell frihet og autonomi i Iran, og mest sannsynlig også uavhengighet. ${ }^{15}$ Det øvrige lederskapet i revolusjonen var imidlertid ikke like klart separatistiske. Blant dem fantes et skille mellom de som i likhet med Pishevari var utdannet i Baku, og de som hadde sin utdannelse fra Teheran.

Bakgrunnen for dette skillet ligger i Sovjetunionens svar på utfordringen fra Woodrow Wilsons doktrine om nasjonenes selvbestemmelsesrett. Sovjetunionen definerte seg da som en overnasjonal enhet, og ga sine språklige minoriteter status som nasjoner. ${ }^{16}$ Dermed ble de som utdannet seg i Baku sosialisert inn i et miljø der det var språklig identitet som dannet grunnlaget for nasjonen. Dette var noe de tok med seg hjem til Iran, og som Pishevaris radikale fløy baserte sin virkelighetsoppfatning på. ${ }^{17}$ Azeri-tyrkere som var utdannet i Teheran hadde imidlertid oppnådd sin posisjon gjennom iranisme og assimilasjon med det persiske, og ønsket ikke å oppgi dette. Touraj Atabakı anser Pishevaris fløy for å ha vært i utakt med folket. ${ }^{18}$ Mye av grunnen til dette kan nettopp være at de, til forskjell fra majoriteten av de iranske azeri-tyrkere, definerte nasjonen ut fra språklig identitet.

I den islamske revolusjonen i I979 fantes det ikke noen eksplisitt azeri-tyrkisk organisasjon eller front, men en av fraksjonene i lederskapet var dominert av azerityrkere. Den azeri-tyrkiske ayatollah Mohammed Kazem Shariatmadari var leder for revolusjonen i Azerbaidjan, og i opptakten til revolusjonen spilte Shariatmadari en sentral rolle også nasjonalt. De viktigste trefningene mellom demonstranter og myndighetene i opptakten til revolusjonen skjedde i Tabriz, ${ }^{\text {I9 }}$ og Khamene'i har uttalt at "Azerbaidjan var aksen i den islamske revolusjonen". ${ }^{2 \circ}$ Shariatmadaris mål var ikke å utfordre Irans territorielle integritet, men han uttrykte skepsis mot den nye konstitusjonen ettersom den ikke ga azeri-tyrkerne mulighet for autonomi. ${ }^{2 \mathrm{r}}$ Dessuten var han i opposisjon mot Khomeini på ideologisk grunnlag. Dagen etter at Shahen forlot landet, publiserte aktivister den første avisen på azeri-tyrkisk, Ulduz, hvor de krevde rettigheter for etniske minoriteter, med spesiell vekt på retten til å bruke det azeri-tyrkiske språket. ${ }^{22}$

\section{Nye media, ny identitet?}

Etter den islamske revolusjonen fulgte krigen mot Irak. Denne ble viktig for hvordan regimet videreførte deler av iranismen som Pahlavi-regimet hadde bygd sin legitimitet på. Shariatmadari var da utmanøvrert og makten konsolidert rundt den mer konser- 
vative Khomeini. Under krigen klarte regimet å lage et betydningsmessig skille mellom islam og arabere på den måten at araberne ble iranismens andre, uten å forkaste islam. ${ }^{23}$ Dermed ble ideen om et

\section{"Det tyrkiske eselet" er en stereotypi av tyrkeren som cerlig, ukultivert, hardtarbeidende og dum.}

iransk folk videreført også etter revolusjonen, og iranismen bestod $i$ en modifisert form. Selv om artiklene I5 og I9 i grunnloven av I979 garanterer de språklige minoritetenes rett til utdannelse og kulturell og språklig utfoldelse, blir disse rettighetene stadig krenket. Dessuten har regimet delt den historiske Azerbaidjanprovinsen i tre deler, og innsatt persere i viktige posisjoner. $^{24}$

I den desperate situasjonen under krigen mot Irak drev det islamske regimet overforbruk av sine propagandamidler. At mange var lei av det lite underholdende iranske tv-tilbudet bidro til at utenlandsk satellitt-tv ble enormt populært da det kom på markedet. I I995 fantes det omlag 500 oo parabolantenner i Teheran, med sine tolv millioner innbyggere. ${ }^{25}$ Det mangler tall for Azerbaidjan, men informanter i Tabriz har bekreftet en lignende situasjon. Da tyrkiske tv-kanaler begynte å sendes via satellitt på begynnelsen av I990-tallet, ble de særlig populære i Azerbaidjan. ${ }^{26} \mathrm{Tv}$ sendingene er naturlig nok preget av en viss forherligelse av det tyrkiske. Disse sendingene har for brede lag av den azerityrkiske befolkningen utfordret det stigmatiserende synet på hva det vil si å være tyrk- er. Kilder i nasjonalistmiljøet i Canada forteller om at dette brakte med seg en endring i nasjonalistenes orientering, og skapte et generasjonsskille. Tidligere hadde aktivistene arbeidet for minoritetsrettigheter og i noen grad også for en iransk føderasjon med azeri-tyrkisk autonomi. Ifølge disse kildene ble nå stadig flere separatister.

Iranske azeri-tyrkere fra den øvre middelklassen har i de senere år begynt å sende barna sine til universiteter i Tyrkia. I Tabriz er det etablert permanente privatskoler, såkalte dershane, med det ene formål for øye å trene elever til inntaksprøven til tyrkiske universiteter. Det er uvisst hvor mange dette dreier seg om. I I945 klarte en håndfull Baku-utdannede iranske azerityrkere å organisere revolusjon i en misfornøyd befolkning. Trolig vil azeri-tyrkere utdannet i dagens Tyrkia bringe med seg ny kulturell selvbevissthet tilbake til Iran. Hvilke politiske konsekvenser dette vil kunne få i dagens Iran, er det imidlertid for tidlig å si noe om.

Mytene som binder en nasjon sammen er som regel langt viktigere enn fakta når nasjonalister skal samle folk om sin sak. Også azeri-tyrkerne i Iran skaper sine myter, men utover enkelte tilløp er ikke disse systematisert til noen "offisiell" nasjonalistisk historiografi. Sentralt i de bidragene som finnes står illusjonen om homogenitet på tvers av grensen til Republikken Azerbaidjan, til tross for nesten to hundre års forskjellige erfaringer, og historier om azeri-tyrkernes bragder i området også forut for tyrkifiseringen. ${ }^{27}$

\section{Güney Azerbaycan Milli Oyanıs Häräkatı}

Spredningen av tyrkiske kulturelle uttrykk i iransk Azerbaidjan sammenfaller i tid med 
den azeri-tyrkiske politikeren Mahmud Ali Chehreganis kandidatur til nasjonalforsamlingen Majlis i I995. Han hadde da en politikk som var, om ikke bent frem nasjonalistisk, så i det minste etnisk inspirert. Ifølge ham selv fikk han 600 ooo stemmer, noe som skulle sikret ham plass. Men han ble nektet plassen av regimet og satt $i$ fengsel. ${ }^{28}$ Da han kom ut, startet han SørAzerbaidjans nasjonale oppvåkningsbevegelse (GAMOH), som arbeidet aktivt i Iran inntil Chehregani gikk eksil i USA i 2004. Kilder i det azeri-tyrkiske eksilmiliøet i Oslo sier at organisasjonen da mistet mye av sin folkelige støtte, samtidig som dens ideologi ble mer radikal.

Hvordan GAMOH presenterer sine mål ser ut til å variere med publikum. Overfor et vestlig publikum erklærte Chehregani i august 2002 at GAMOH ikke ønsket forening med Republikken Azerbaidjan, men jobbet for et føderalt Iran. ${ }^{29}$ For øvrig har GAMOH uttalt at azeri-tyrkisk burde innføres som et andrespråk i skolen i de azerityrkiske områdene i stedet for arabisk..$^{30}$ Dette står i kontrast til budskapet Chehregani hadde til det tyrkiske nasjonalistpartiet MHPs ungdomsorganisasjon De grå ulvene i april 2002. Hos dem siterte han Republikken Azerbaidjans gamle president, Elçibey, og sa at også han mente at "veien til den tyrkiske verden går gjennom Tabriz”. ${ }^{\text {I }}$ Elçibey er kjent for å ha ønsket å forene iransk Azerbaidjan med Republikken Azerbaidjan, og sitatet må tolkes dit hen at Chehregani ønsker en form for forening med andre tyrkiske stater.

På GAMOHs hjemmesider klargjør de sine politiske og territorielle aspirasjoner. Der gjør de krav på provinsene Øst-Azerbaidjan, Vest-Azerbaidjan, Ardabil, Zanjan, Hamadan og Qazvin. I alt dreier dette seg om 350.000 kvadratkilometer, et område på størrelse med Norge. De skriver: "I Tabriz skal våre nasjonale rettigheter opprettes, vi skal få et nasjonalt parlament og et nasjonalt politi”. Særlig interessant er hvordan GAMOH omtaler andre grupper i området. Perserne omtales som "våre fiender". Om kurdere: "Dersom de oppfører seg normalt, vil det ikke bli noe problem, "Hvis ikke, skal kurderne dra slik de kom." ${ }^{2}$ Slik GAMOH formulerer azerityrkisk nasjonalisme, er det ikke bare perserne som blir azeri-tyrkernes andre, men også kurderne.

\section{Nettverksbasert aktivisme}

Etter at GAMOHs ledelse flyktet fra Iran i 2004 har den azeri-tyrkiske nasjonalistbevegelsen blitt mer pluralistisk. Det meste av organiseringen skjer nå gjennom nettverk. Den har ingen eksplisitt ledelse, men aktivister samles rundt det kilder i miljøet kaller en "menneskerettighetsideologi”, der respekt for menneskerettighetene er hovedmålet. Aktivistene har ukentlig åpne møter på internettbaserte messenger-tjenester, der 60-Ioo aktivister deltar. Dette skjer over landegrensene, og senker barrieren mellom eksilmiljøet og de som er i Iran. I kampen mot den iranske staten har den azeri-tyrkiske bevegelsen også kontakt med andre folkegrupper i Iran. Frem til nå har de ikke samarbeidet med den persiske delen av opposisjonen, som de mener ikke vil akseptere minoritetsrettigheter.

Denne delen av den azeri-tyrkiske bevegelsen har en ideologi som skiller seg fra den som tidligere er skissert $i$ forbindelse med GAMOH. Kilder i denne delen av nasjonalistbevegelsen refererer til Sør-Afrikas ANC som en modell for den 
videre utviklingen. En nasjonalstat sees som et middel for å skape et demokrati med respekt for menneskerettighetene, og ikke som et mål i seg selv. Aktivister av denne typen sier ofte at de har blitt nasjonalister fordi de er lei av at perserne er for lite aktive i kampen for demokrati. I februar 2008 stilte nobelprisvinneren Shirin Ebadi opp på et møte i en forening som jobber for azeri-tyrkiske politiske fanger, og oppfordret dem til å sende saker videre til hennes organisasjon. ${ }^{33}$ Dette kan være kimen til et samarbeid mellom deler av den

\section{2. mai 2006 trykket avisen Iran en karikatur som fremstilte en azeri- tyrker som en kakerlakk.}

azeri-tyrkiske bevegelsen og persiske menneskerettighetsforkjempere, men det er det for tidlig å si noe mer om.

Nettverksorganiseringen gjør bevegelsen mindre sårbar overfor arrestasjoner og lignende, men gjør det samtidig vanskeligere å kommunisere med omverden. Ettersom mange azeri-tyrkere ikke er særlig skrivekyndige og har lite kjennskap til fremmedspråk, har nasjonalistene problemer med å spre sitt budskap. De lærer ikke å skrive sitt morsmål på skolen, og ikke alle mestrer persisk etter endt skolegang.

Internett har gjort nettverksorganisering effektiv, og bevegelsen tar stadig i bruk ny teknologi. Nye ideer og ny ideologi spres dermed raskt $\mathrm{i}$ alle deler av bevegelsen. Azeri-tyrkere har de senere årene også fått sin egen tv-kanal, GünAz, som sender fra
Chicago. I tillegg har internett begynt å gi satellittene konkurranse som overføringsmedium av tv-signaler og GünAz finnes nå bare tilgjengelig på nett-tv. ${ }^{34}$ Nye nett-tv og -radiokanaler skal også være under planlegging.

\section{Demonstrasjoner og aktivisme}

I2. mai 2006 trykket den statskontrollerte avisen Iran i sin spesialutgave for barn en karikatur som ikke bare fremstilte en azerityrker som kakerlakk, men som til alt overmål diskuterte hvordan kakerlakkene skal utryddes. Det ble påstått at diskusjoner ikke nyttet og heller ikke vanlig vold, man måtte ta fra kakerlakkene deres livsgrunnlag: avføring.

Azeri-tyrkere gikk ut på gatene i Teheran og mange byer i iransk Azerbaidjan. Amnesty International anslo den største demonstrasjonen i Tabriz 22. mai til å ha bestått av mellom 300 oo० og 500 000 mennesker. ${ }^{35}$ Irans offisielle mediers anslag lå naturlig nok mye lavere, på 20 ooo demonstranter på det meste. ${ }^{36}$ Regimet svarte dagen etter med å stenge avisen som hadde trykket karikaturene, og denne forble stengt i fem måneder.37 Da demonstrasjonene hadde pågått $i$ to uker, satte styresmaktene inn militære styrker og stoppet uroen..$^{3}$ Ifølge internasjonale medier ble fire personer drept og 43 skadet. ${ }^{39}$ Amnesty International kunngjorde at de hadde mottatt navnene på $27{\text { døde. }{ }^{40}}^{\circ}$

Demonstrasjonene fikk sitt etterspill. I juli 2006 besøkte president Mahmoud Ahmedinejad iransk Azerbaidjan. Han lovet mer penger til veier og en ny fabrikk, og siterte dikt på azeri-tyrkisk. Fra azerityrkisk nasjonalistisk hold blir det imidlertid hevdet at besøket var strengt regissert. Ifølge dem var de fremmøtte tilskuerne 
statsansatte og landsbyboere som ble presset til å delta. Videre hevder de at kjente nasjonalister hadde blitt arrestert i forkant av besøket..$^{4}$ Etter demonstrasjonene skrev også Akbar Alami, Majlis-representant for Tabriz, et åpent brev til lederen for domstolene der han protesterte mot arrestasjonen av demonstranter. Han mente at disse bare hadde vist sin uendelige kjærlighet til sitt språk, kultur og historie, og at de ikke var ekstremister, men ønsket full implementering av Grunnlovens artikler I5 og I9. ${ }^{42}$ Det er verd å merke seg at ettårs-dagen for karikaturdemonstrasjonene i mai 2007 ble markert med nye demonstrasjoner i Tabriz, der minst I5 demonstranter ble arrestert. ${ }^{43}$

Selv om denne karikaturstriden så langt er det sterkeste uttrykket for azeri-tyrkisk etnisk mobilisering, er dette ikke enestående. I januar 2000 skal politiet ha åpnet ild mot en større demonstrasjon i Tabriz. ${ }^{44}$ Til forskjell fra tidligere demonstrasjoner i byen etter den islamske revolusjonen, var ikke denne en del av noen nasjonal bølge av protester. I løpet av de siste årene har også den internasjonale morsmålsdagen 2I. februar blitt en anledning for azeri-tyrkiske demonstrasjoner. I 2007 ble den markert med store demonstrasjoner mot den iranske statens undertrykkelse av det azeri-tyrkiske språket, der minst 80 personer skal ha blitt arrestert. ${ }^{45}$

I månedsskiftet juni/juli hvert år feirer azeri-tyrkerne tradisjonelt den historiske figuren Babek med en festival som starter med en marsj til hans fort i Kaleybar i Ardabil-provinsen. Babek var en krigsherre i Azerbaidjan i det niende århundre, og blir ansett som en lokal helt fordi han lenge holdt den arabiske invasjonshæren ute av området. At dette var forut for tyrkifiserin- gen, ser ikke ut til å hindre ham i å være et sterkt nasjonalsymbol. I 2002 ble marsjen til Kaleybar brutt opp av politiet, ${ }^{46}$ og i 2004 ble festivalen fulgt opp med en omfattende demonstrasjon i Tabriz. ${ }^{47}$ Iranske myndigheter gjennomførte en offensiv mot azeri-tyrkisk media, de stengte aviser og nettsider og arresterte redaktører i forkant av festivalen i $2006.4^{8}$ Ifølge pressebyrået APA i Republikken Azerbaidjan, hadde iranske sikkerhetsstyrker satt opp veisperringer $\mathrm{i}$ en I50 kilometer radius rundt fortet og innførte i praksis unntakstilstand i området. ${ }^{49}$ Også i 2007 ble veien til Kaleybar stengt da Babekfestivalen skulle avholdes, og flere ble arrestert. ${ }^{50}$ Som svar på dette ble det holdt store azeri-tyrkiske demonstrasjoner i Tabriz..$^{\text {I }}$

\section{Radikalisering av nasjonalismen?}

I en situasjon med stor misnøye med styresmaktene kan det iranske styrets legitimerende prinsipp være i en utsatt posisjon. Iranismen og islamismens monopol på azeri-tyrkernes primære identitet har fått en utfordring fra azeri-tyrkisk nasjonalisme. Dersom en azeri-tyrkisk identitet får forrang for den iranske for en tilstrekkelig andel av befolkningen, kan regimets stabilitet bli truet. Det er vanskelig å måle nasjonalismens popularitet. Dens videre utvikling avhenger av en rekke faktorer som nasjonalistene selv har liten kontroll over. En av disse er kombinasjonen av misnøye med regimet i Iran og undertrykkelse av azeri-tyrkiske kulturelle uttrykk, med lett tilgang på kulturelle uttrykk fra Tyrkia og Republikken Azerbaidjan.

Når regimet bekrefter nasjonalistenes forestillinger ved å reagere med undertrykkelse, blir det vanskeligere for azeri- 
tyrkere å slutte opp om iranismen. En annen faktor er spenningsnivået mellom Iran og Tyrkia. Med et lavt spenningsnivå mellom de to landene, er det mindre farlig å bli assosiert med tyrkerne. At Tyrkias militante sekularisme har blitt myket opp av AKP-styret gjør det også lettere for azerityrkere i Iran å identifisere seg med Tyrkia. Om ideologien om menneskerettigheter, demokrati og organisering gjennom organiske nettverk fortsetter, er det mindre sannsynlig at det vil resultere i voldelig ekstremisme. Fraværet av organisert vold kan ha den effekten at nasjonalistbevegelsen får et moralsk overtak på staten, særlig om staten fortsetter å undertrykke den. Så gjenstår det å se hvilke idealer som veier tyngst om staten øker presset ytterligere, kanskje begynner nasjonalistene å tro at målet helliger middelet. Uavhengig av hvilken strategi de velger, er dette en bevegelse som kan få store konsekvenser for Iran og regionen, og kanskje også verden. Det er derfor verdt å følge med på utviklingen og studere denne nasjonalismen nøye.

\section{$\cdot f \cdot$}

I “Perser" er her brukt i betydningen "personer med farsi som morsmål". "Persisk" som språk er heller ikke ment å bety annet enn farsi. Begrepene er valgt på grunn av at de lett lar seg forstå uten omfattende diskusjoner. For omfattende diskusjoner se: Vaziri, Mostafa (I993): Iran as Imagined Nation: The Construction of National Identity, New York: Paragon House

2 Definisjonene av "tyrker", "azeri”, "Azerbaidjaner", "Azerbaidjantyrker" og "iraner" er gjenstand for debatt, og materiale for en egen artikkel. De jeg her omtaler som "azeri-tyrkere" i Iran kaller seg selv, og blir kalt av andre iranere, for "tyrkere". Da det å bruke ordet "tyrker" på norsk ville i for stor grad implisert at de er en sømløs forlengelse av tyrkerne i Tyrkia, har jeg bevisst valgt å unngå det. "Azerbaidjaner" er også valgt bort, ettersom dette begrepet er sterkt knyttet til Republikken Azerbaidjan. "Azeri” brukes i Iran som en fellesbetegnelse på alle innbyggerne i Irans to Azerbaidjan-provinser, og benyttes som et rent geografisk begrep. "Azeri-tyrker" er valgt fordi det er en kombinasjon av den geografiske betegnelsen og den etniske betegnelsen de bruker på seg selv. For det nasjonalistiske synet på saken se: gamoh.org/ muraciet/bakida5.html (lesedato I2.02.2008)

3 CIA (2007): "CIA - The World Factbook - Iran", www.cia.gov/library/publications/the-world-factbook/ geos/ir.html, (lesedato I4. juni 2007).

4 Ethnologue: "Ethnologue report for Iran", ethno logue.com/show_country.asp?name=IR, (lesedato June I4, 2007)

5 Tapper, Richard (1983): "Introduction" i Tapper, Richard (red): The Conflict of Tribe and State in Iran and Afghanistan, London: Croom Helm, s. I-82.

6 Golden, Peter B. (1992): An Introduction to the History of the Turkic Peoples, Wiesbaden: Otto Harassowitz.

7 Yelvington, Kevin (I99): “Ethnicity as practice? A comment on Bentley" i Comparative Studies in Society and History, vol.33, nr.I, s.I58-68

8 Selvik, Kjetil \& Stig Stenslie (2007): Stabilitetens pris: Stat og politikk i Midtøsten, Bergen: Fagbokforlaget.

9 Vaziri, Mostafa (I993): Iran as Imagined Nation: The Construction of National Identity, New York: Paragon House.

Io Vaziri, Mostafa (I993): Iran as Imagined Nation: The Construction of National Identity, New York: Paragon House.

II Touraj Atabakı (200I): "Recasting Oneself, Rejecting the Other: Pan-Turkism and Iranian Nationalism”, i Willem van Schendel \& Erik J. Zürcher (red.): Identity Politics in Central Asia and the Muslim World: Nationalism, Ethnicity and Labour in the Twentieth Century, London: I.B. Tauris.

I2 Vaziri, Mostafa (I993): Iran as Imagined Nation: The Construction of National Identity, New York: Paragon House.

I3 Schaffer, Brenda (2002): Borders and Brethren, Cambridge \& London: MIT Press.

I4 Cornell, Svante (2004): “Iranian Azerbaijan: A Brewing Hotspot”, upublisert paper presentert på symposiet "Human Rights and Ethnicity in Iran", Stockholm, 22. November 2004 .

I5 Atabak1, Touraj (2000): Azerbaijan: Ethnicity and the Struggle for Power in Iran, London: I.B. Tauris.

I6 Laçiner, Sedat og Turgut Demirtepe (2004): “Nationalism as a Socialist Foreign Policy: The Southern Azerbaijan Problem In Soviet-Iranian Relations", Review of International Affairs, vol.3, nr.3, s.443-57.

I7 Atabakı, Touraj (2000): Azerbaijan: Ethnicity and the Struggle for Power in Iran, London: I.B. Tauris.

I8 Atabak1, Touraj (2000): Azerbaijan: Ethnicity and the Struggle for Power in Iran, London: I.B. Tauris.

I9 Fischer, Michael M. J. (I980): Iran: Religious Dispute to Revolution, Cambridge MA: Harvard U.P.

20 Karimi, Nasser (2006): “U.S. will fail to spark unrest", Associated Press, 28. mai 2006.

2I Intervju med Shariatmadari i “Mundo Obrero" (Madrid), 
9. desember 1979 og Cumhuriyet (Istanbul), 6. mars I979, sitert i Schaffer, Brenda (2002): Borders and Brethren, Cambridge \& London: MIT Press.

22 E. Ch. Babaev, "Iuzhnyi Azerbaidzhan v iranskoi revoliutsii I978-I979 gg”, i Jänubi Azärbayjan Tarikhi Mäsäläläri (Baku: Elm, I989) i Schaffer, Brenda (2002): Borders and Brethren, Cambridge \& London: MIT Press.

23 Vaziri, Mostafa (I993): Iran as Imagined Nation: The Construction of National Identity, New York: Paragon House.

24 Souleimanov, Emil (2006): “The 'Cartoon Crisis' in Iranian Azerbaijan: Is Azeri Nationalism Underestimated?” i Central Asian-Caucasus Analyst, vol.8, nr.I2, s.8-Io.

25 Barraclough, Steven (200I): "Satellite Television in Iran Prohibition, Imitation and Reform”, Middle Eastern Studies, vol.37, nr.3, s.25-48.

26 Tyrkias første kommunikasjonssatellitt, TurkSat IB, ble skutt opp i august I994. cscrs.itu.edu.tr/page. en.php?id=39 (lesedato 26.I2.2007)

27 Se Schaffer, Brenda (2002): Borders and Brethren, Cambridge \& London: MIT Press, og Asharzadeh, Alireza: "In Search of a Global Soul: Azerbaijan and the Challenge of Multiple Identities", Middle Eastern Review of International Affairs, vol.II, nr.4, s.7-I8.

28 Olson, Robert (2002): “The 'Azeri' Question and TurkeyIran relations, 2000-2002", Nationalism and Ethnic Politics, vol.8, nr.4, s.6I- 85 .

29 Olson, Robert (2002): “The 'Azeri' Question and TurkeyIran relations, 2000-2002", Nationalism and Ethnic Politics, vol.8, nr.4, s.6I- 85 .

30 Human Rights Watch (I997): Iran - Religious And Ethnic Minorities: Discrimination in Law And Practice, I997 report, hrw.org/reports/1997/iran/Iran-o6.htm (lesedato 30.08.2007)

3I Turkish Daily News, 7. mai 2002.

32 GAMOH: "Güney Azerbaycanın Derdlerini Dünyaya Çatdırdıq” gamoh.org/muraciet/bakida5.html (lesedato 05.01.2008) [Forfatterens oversettelser]

33 "Tale av Mohandes Sarrafi i Foreningen av forsvarere av menneskerettigheter til forsvar for azeri-tyrkiske politiske fanger" (persisk) http://azadtribun.net/xi886r.htm (lesedato I3.02.2008)

34 GünAz TV er nå tilgjengelig fra www.günaz.tv.

35 Amnesty International (2006): "Hundrevis arrestert etter demonstrasjon”, 29.05.2006. amnesty.no/web.nsf/ pages /5D62DCAE3A40I6CDCi257I7Do02AE6C8 (lesedato II. februar 2008)

36 Radio Free Europe/Radio Liberty (2006): "Iranian Azeris Continue Protests", 24.05.2006. rferl.org/featuresarticle/ 2006/05/01248386-bbab-4d37-b94I-adb88ige3bir.html (lesedato II. februar 2008)

37 BBC News (2006): "Iranian paper banned over cartoon", 23.05.2006 news.bbc.co.uk/2/hi/middle_east/ $5008420 . \mathrm{stm}$ (lesedato 20. februar 2007)
38 Souleimanov, Emil (2006): “The 'Cartoon Crisis' in Iranian Azerbaijan: Is Azeri Nationalism Underestimated?", Central Asian-Caucasus Analyst, vol.8, nr.I2, s.8-ıо.

39 Se for eksempel "Four Killed in Iran's Ethnic Unrest," bakutoday.net/view.php?d=21603 (lesedato 6. juni 2007). Eller "Iranere døde under protest mot avistegning" i Aftenposten, Oslo, 29. mai 2006

40 Amnesty International (2006): "Iran - Authorities should exercise restraint in policing Babek Castle gathering and address human rights violations against Iranian Azeri Turks", Public Statement, AI Index I3/074/2006

4I "Iran: Ethnic Azeri Activist Predicts More Protests" eurasianet.org/departments/civilsociety/articles/eavo 73106.shtml (lesedato 29.08.2007)

42 "Lawmaker Blames Government Discrimination for Ethnic Strife", Baybak.com, I5. juni 2007 en.baybak.com/ lawmaker-blames-government-discrimination-for-ethnicstrife.azr (lesedato I7.02.2008).

43 Radio Free Europe (2007): "Iran Arrests I5 For Encouraging Azeri Protests", 22. mai 2007. rferl.com/features article/2007/05/a806563e-6If2-43ab-909a-54d4a8 $48 \mathrm{c} 33 \mathrm{c} . h \mathrm{html}$ ?napage $=2$ (lesedato 27.08.2007)

44 BBC (2000): "Azeri TV Says Iranian Police Opened Fire During a Rally in Tabriz", BBC Summary of the World Broadcasts, januar 2000, og BBC (2000): "Iranian police disperse rally", BBC News 07.0I.2000, news.bbc.co.uk/ 2/hi/middle_east/594537.stm (lesedato 20.02.2007).

45 Rahder, Karl (2007): "Stifling the Azeris", ISN Security Watch, 26/04/07 isn.ethz.ch/news/sw/details.cfm? id=I7540 (lesedato I7.02.2008)og Rahder, Karl (2007): "The 'Southern Azerbaijan' Problem", ISN Security Watch, I9/04/07 isn.ethz.ch/news/sw/details.cfm?ID= I7508 (lesedato I7.02.2008)

46 BBC Monitoring (2002): "Ethnic Azeri in Iran Gets Prison Sentence Following March to Fort - Azeri Paper" BBC Monitoring International Reports, 5. august 2002.

47 BBC Monitoring (2004): "Paper Reports High Turnout in Azeri March in Iran", BBC Monitoring International Reports, 4. juli 2004.

48 Mughanli, Said: "Iranian Intelligence Services Ban Access to Azerbaijani Websites" today.az/news/society/2780I. html (lesedato 30.08.2007)

49 "Azerbaijanis in Iran Prevented to March to Bazz Tower", today.az/news/politics/27744.html (lesedato 30.08.2007)

50 "Police Atmosfer [sic], Heavy Guarded Forces Inside and Out of Azerbaijani Cities", en.baybak.com/police-atmos fer-heavy-guarded-forces-inside-and-out-of-azarbaijanicities.html (lesedato 30.08.2007)

5I "Mass Protest Took Place in Tabriz, Reports Say" en.baybak.com/mass-protest-took-place-in-tabriz-reportssay.html (lesedato 30.08.2007) 